\title{
ASSUNNA' CULTURAL HEALTH IMPLICATIONS (STUDY OF HEALTH ANTHROPOLOGY IN BONTORAMBA COMMUNITY, JENEPONTO REGENCY)
}

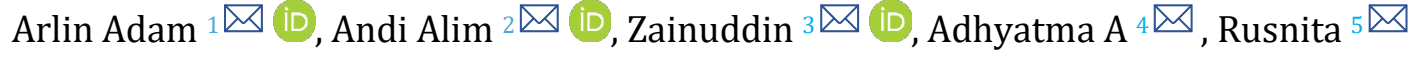 \\ ${ }^{1}$ Professor, Public Health, University of Pejuang Republic Indonesia, Makassar City, South Sulawesi Province, \\ Indonesia \\ ${ }^{2}$ Lector, Public Health, University of Pejuang Republic Indonesia, Makassar City, South Sulawesi Province, \\ Indonesia \\ ${ }^{3}$ Lector, Public Health, University of Pejuang Republic Indonesia, Makassar City, South Sulawesi Province, \\ Indonesia \\ 4,5 Expert Assistant, Public Health, University of Pejuang Republic Indonesia, Makassar City, South Sulawesi \\ Province, Indonesia
}

Received 03 December 2021

Accepted 01 January 2022

Published 23 February 2022

\section{CorrespondingAuthor}

Andi Alim,

andi_alimbagu@yahoo.co.id

DOI 10.29121/IJOEST.v6.i1.2022.285

Funding: This research received no specific grant from any funding agency in the public, commercial, or not-for-profit sectors.

Copyright: (C) 2022 The Author(s). This is an open access article distributed under the terms of the Creative Commons Attribution License, which permits unrestricted use, distribution, and reproduction in any medium, provided the original author and source are credited.

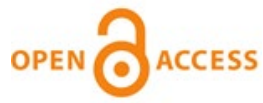

\section{ABSTRACT}

Male circumcision is beneficial and does not doubt health. So many studies show that male circumcision can prevent several diseases. In Jeneponto, some parents choose their children to practice Assunna' culture. The purpose of this study was to obtain information, examine and analyze in depth the health implications of Assunna' culture in the Bontoramba community, Jeneponto Regency. The research method used is qualitative with an ethnographic approach. Informants were drawn purposively with the snowball technique. The number of informants is 7 people (two regular informants, two supporting informants, and one key informant). The results showed that the Assunna' culture in the Bontoramba community was carried out by circumcision officers (hamlet priests). Circumcision officers do not wash their hands before starting the circumcision process. Chicken blood is smeared on the cut skin as a form of unification and followed by giving firewood ashes by sprinkling or smearing it directly. People who believe in taboo are not allowed to come out of the house and step on chicken manure and horse manure after being circumcised. When violated, will cause pain in the part that has been cut the skin. The circumcision process begins with sprinkling water on the genitals three times, reading a prayer and then blowing it into water which is believed to remove uncleanness and accelerate wound healing. The skin that is removed is only a little which is important to bleed so that the child's blood can be united with chicken blood. The pain experienced by the child lasts for one to two days. In conclusion, the health implications of Assunna' culture can lead to infection risk, disease prevention, and the concept of health and illness. It is hoped that collaboration between doctors/nurses and village priests in Assunna' cultural rituals is expected.

Keywords: Health Implications, Infection Risk, Disease Prevention, Sick Health Concept, Assunna' Ritual, Jeneponto

\section{INTRODUCTION}

Male circumcision is beneficial and does not doubt health. So many studies show that male circumcision can prevent several diseases. Circumcision in the medical world is carried out by trained health workers who have obtained permission and are supported by the availability of sterile 
equipment and the use of personal protective equipment such as hands-on and masks. However, in some areas in Indonesia, circumcision has a cultural meaning so that the process of child circumcision is usually carried out based on prevailing local customs.

For the Jeneponto community, circumcision symbolizes a transition in human development that usually causes a crisis. Therefore, humans respond to the implementation of the ceremony. One of the ceremonies that are often performed by the Jeneponto community is assunna'. The assunna' ceremony is one part of the life cycle ceremony for the Jeneponto community, whose implementation is very lively, equivalent to a wedding party. This is intended, because assunna 'is a very basic Islamic process for every Jeneponto community to enter the age of puberty, Fatmawati (2015).

Based on an initial survey at the research site that has received information from the hamlet priest, people who perform circumcision on boys prefer the assunna 'culture where circumcision is carried out by the hamlet priest. The practice of circumcision in the Bontoramba community is different from medical circumcision, in that the boy sits on a banana tree trunk that has just been cut down, then the village priest recites a mantra and then blows it, and the tip of the foreskin is cut slightly using a razor blade, the priest does not wear gloves. (Handscoon) so that the hands cannot be ensured that they are sterile or clean from bacteria, germs, and viruses. This assunna culture is carried out on elementary school-aged children so that they do not perform medical circumcision until adulthood, some even perform medical circumcision after marriage. This assuna' cultural tradition has been carried out by their ancestors which has been passed down from generation to generation to this day.

Research Maksum (2015) revealed that the practice of assuna which is different from Islamic law was also carried out by the people of Tengger Village, Probolinggo. Circumcision is performed only to slice the skin of the male genitalia until it bleeds, whereas in Islam, part of the skin at the tip of the penis must be cut off to maintain cleanliness.

In terms of religion, $90 \%$ of Indonesia's population is Muslim. It is a must for a Muslim male to perform circumcision. Circumcision of Muslim men can protect them as well as women from HIV infection. Based on UNAIDS data in 2008 circumcision reduces the risk of HIV infection by up to $60 \%$ through other types of sexual intercourse LeMone et al. (2015).

According to the study of Drain et al. (2006), showing that male circumcision can reduce the risk of HIV transmission and reduce the risk of cervical cancer in women, especially in countries where HIV transmission is through heterosexual intercourse (not applicable in Indonesia). countries where HIV is transmitted through drug use or homosexuality).

Another study related to circumcision and culture in research Ramli (2015) found that the Alifuru community considers the birth of a child to be a sacred process that must be accompanied by traditional ritual ceremonies in the form of circumcision so that the new-born child is not exposed to bad luck from the ancestors and is protected from curses. sick, have no offspring, are not recognized as an Alifuru community group, and do not carry out customs. According to their opinion, people who have not been circumcised are people who are still dirty.

According to an official report from the United States Centers for Disease Control and Prevention (CDC), Circumcision has been medically proven to reduce the risk of contracting infectious diseases, male urinary tract infections, and penile cancer. The $\mathrm{CDC}$ says there is strong evidence that male circumcision can reduce the risk of HIV infection in female partners by $50-60 \%$. Circumcision also reduces the 
risk of developing genital herpes, Sexually Transmitted Diseases (STD) and certain strains of the human papillomavirus by 30 per cent or more. Not only that, but another benefit of circumcision is also to reduce the chances of urinary tract infections in infancy and penile cancer in adulthood. Circumcision needs to be done because germs will grow under the foreskin based on the findings of Dr Aaron Tobian, a researcher at Johns Hopkins University in one of his studies in Africa Erviana (2014). WHO reported a significant increase in cases of circumcision surgery between 2011-2012, namely in 2011 as many as 140 million patients and 2012 as many as 148 million patients? In Indonesia, there are 1.2 million patients Hartoyo (2015).

The importance of circumcision in the prevention of infectious diseases then faces challenges because, in certain communities, especially the people of Jeneponto, South Sulawesi, Indonesia, circumcision is interpreted as a cultural event that is full of circumcision traditions that can potentially cause disease infections. Based on this description, the researcher is interested in studying the health implications of Assunna' culture in the Bontoramba Community, Jeneponto Regency.

\section{METHODS}

\subsection{APPROACH AND TYPE OF RESEARCH}

This type of research is a type of qualitative research with an ethnographic approach that intends to find out the cultural implications of village circumcision in the Bontoramba sub-district, Jene Ponto district. By using in-depth interview techniques (In-depth Interview) and observation as well as Focus Group Discussion (FGD) and documentation during the research.

\subsection{RESEARCH INSTRUMENTS}

The instrument in this research is self-research wherein carrying out the research, the research equips itself with: 1) an mp3 tape recorder or cell phone which functions to record during the interview process; 2) Digital camera to photograph the process in the field; 3) Interview guidelines for in-depth interviews; 4) FGD interview guide (Focus Group Discussion), and 5) Additional notes that function to record the results of observations that set the context of the event.

\subsection{RESEARCH LOCATION AND TIME}

This research will be carried out in September 2020 in the community of Bontoramba sub-district, Jeneponto district, South Sulawesi province because in this area circumcision is considered an integral part of the traditional procession.

\subsection{RESEARCH INFORMANTS}

Informants were selected based on snowball sampling while key informants and supporting informants were selected based on purposive or those who met the following criteria: 1) Key Informants: a) Traditional Figures; b) Hamlet Imam; and c) Shaman. 2) Main Informants Children who practice as Sunna' culture; 3) Supporting Informants: a) Parents and b) Health Officers.

\subsection{DATA SOURCE}

Primary data sources used in this study include: a) Parents who choose village circumcision culture for their children; b) traditional leaders, hamlet priests, shamans, health workers; c) family. 


\subsection{DATA COLLECTION TECHNIQUE}

Data collection techniques were carried out using participatory observation, indepth interviews (In-depth-interview), and documentation, as well as FGD (Focus Group Discussion).

Observations were carried out before going down directly to review informants, as well as during data mining. Observation is needed to know the research context. Interviews were conducted after going through direct observation. Interviews were conducted continuously until the data or information obtained were at a saturated level.

The method of documentation is to collect data in the form of video images or writing, which proves that the researcher is doing the research and supports the requirements of research. This process is to collect information for each individual and summarize all the answers from each participant to be used as a guide for researchers, another purpose of FGDs is to solve a problem by taking all the inputs given by FGD participants. This process is carried out in groups of at least 5 people.

\subsection{DATA ANALYSIS TECHNIQUE}

Data analysis techniques are carried out in stages starting from data reduction, data display, and conclusion drawing. The data reduction process is carried out by selecting the main things that make up the research theme, data displays are developed to provide a brief description of the data in the form of categories, flowcharts, factsheets, and others. While the conclusion is a temporary formulation of the overall research results that still require triangulation to arrive at conclusions that are valid and credible.

\subsection{DATA VALIDITY}

The data validity techniques in this study are 1) Triangulation of sources, namely using various data sources through different sources, namely key informants, main informants, and supporting informants; 2) Triangulation of methods/techniques, namely collecting similar data but different techniques or collection methods using FGD (Focus Group Discussion), in-depth interviews, observation and documentation; 3) Theory triangulation, namely the use of various theories to ensure that the data collected has entered the requirements and confirms the related theories that have been described in the literature review; and 4) time triangulation, namely testing data in different times and situations.

\section{FINDINGS}

\subsection{CHARACTERISTICS OF INFORMANTS}

\begin{tabular}{|cccccc}
\hline \multicolumn{5}{c}{ Table 1 Characteristics of FGD Participants (using initials) } \\
\hline No. & Name & Age & Education & Work & Address \\
\hline 1 & HR & 29 & Bachelor & Nurse & Pokobulo \\
\hline 2 & HL & 46 & Junior High School & Hamlet Priest & Batu-batua \\
\hline 3 & L & 34 & Senior High School & Housewife & Batu-batua \\
\hline 4 & R & 13 & Junior High School & Student & Batu-batua \\
\hline 5 & I & 10 & Primary School & Student & Batu-batua \\
\hline 6 & NFT & 26 & Bachelor & Nurse & Balumbungan \\
\hline 7 & SAY & 26 & Diploma 4 & Student & Karampuang \\
\hline 8 & SS & 28 & Diploma 3 & Midwife & Pokobulo \\
\hline
\end{tabular}


Based on the Table 1 explained that the FGD (Focus Group Discussion) was held on October 18, 2020, at 16:07 WITA and the participants were 8 people of different ages, occupations and education. The number of participants in the FGD (Focus Group Discussion) was 8 people, namely: 1) HR is 29 years old, last education is a bachelor's degree in nursing who works as a nurse and operator of medical circumcision at the Bontoramba Health Center and comes from Pokobulo. In this case as a health worker; 2) HL is 46 years old, his last education in junior high school who works as a hamlet priest in Datara Village and comes from Batu-Batua. In this case as a village circumcision officer; 3 ) $\mathrm{M}$ is 34 years old, his last education is high school and works as a housewife and comes from Batu-Batua. In this case as a parent. 4) $\mathrm{R}$ is 13 years old, his last education in junior high school who works as a student and comes from Batu-Batua. In this case as a child who does assunna' culture; 5) I am 10 years old, my last education in elementary school, working as a student and comes from Batu-Batua. In this case as a child who does assunna' culture; 6) NFT is 26 years old, his last education is Bachelor of Nursing who works as a nurse at the Bontoramba Health Center and comes from Balumbungan. In this case, as a child who does the assunna culture '. 7) SAY is 26 years old, Diploma 4 education who works as a student and comes from Karampuang. In this case as a researcher; and 8) SS is 28 years old, has a Diploma 3 education who works as a midwife and comes from Pokobulo. In this case as a note.

Based on the characteristics of the informant using the FGD (Focus Group Discussion) technique, it was found that the informant provided information expressed by the informant about the health implications of Assunna' cultural anthropology studies in the Bontoramba community, Jeneponto district. In the implementation of the FGD (Focus Group Discussion), the first thing that was carried out was the researcher explained the purpose of this study so that the participants had the same perception as the researcher. The discussion in the implementation of the FGD (Focus Group Discussion) is the health implications of the Assunna culture in the study of health anthropology in the Bontoramba community, Jeneponto district. The discussion was brought by the researcher.

\begin{tabular}{|c|c|c|c|c|c|c|}
\hline No. & Name & Age & Education & Work & Address & No.2 \\
\hline 1 & I & 10 & $\begin{array}{c}\text { Primary } \\
\text { School }\end{array}$ & Student & Batu-batua & \\
\hline 2 & $\mathrm{R}$ & 13 & $\begin{array}{c}\text { Junior High } \\
\text { School }\end{array}$ & Student & Batu-batua & $\begin{array}{l}\text { Ordinary } \\
\text { Informants }\end{array}$ \\
\hline 3 & EKT & 20 & Bachelor & Student & Balumbungan & \\
\hline 4 & NFT & 26 & Bachelor & Nurse & Balumbungan & \\
\hline 5 & HL & 46 & $\begin{array}{c}\text { Junior High } \\
\text { School }\end{array}$ & $\begin{array}{c}\text { Hamlet } \\
\text { Priest }\end{array}$ & Batu-batua & $\begin{array}{c}\text { Key } \\
\text { Informants }\end{array}$ \\
\hline 6 & $\mathrm{~L}$ & 34 & $\begin{array}{c}\text { Senior High } \\
\text { School }\end{array}$ & Housewife & Batu-batua & $\begin{array}{l}\text { Supporting } \\
\text { Informants }\end{array}$ \\
\hline 7 & HR & 29 & Bachelor & Nurse & Pokobulo & \\
\hline
\end{tabular}

Based on Table 2. Explains that this research took place from October 15 to November 15, 2020, in the Bontoramba community. In the implementation of indepth interviews, the number of informants was 7 people, from 4 regular informants, 1 key informant and 2 supporting informants.

There are 4 regular informants, namely: 1) The EKT informant is 20 years old, the last education of the S1 informant is working as a student. The informant came from Balumbungan. The informant did assuna' culture when he was in 5 th grade and he was 11 years old. Informants consider doing assunna culture because of the 
wishes of their parents; 2) The NT informant is 25 years old, the last education of the informant is Bachelor of Nursing working as a nurse at the Bontoramba Community Health Center. The informant came from Balumbungan. Informants do assunna' culture at the age of 9 years. Informants consider doing assunna' culture because of the wishes of their parents which has become a hereditary habit in their family; 3) The DFS informant is 10 years old, his last education in elementary school, working as a student. Informants come from Batu-Batua. The informant did assuna' culture 2 months ago. The informant considered doing assunna' culture because his parents said it was for his good; 4) Informant R is 13 years old, his last education in junior high school, working as a student. Informants come from Batu-Batua. The informant did assuna' culture at the age of 10 years. The informant considered doing assunna' culture because of the will of his parents and he said it was his destiny to be circumcised. Meanwhile, the Key Informants are 1 person, namely: Community Leader as a village circumcision officer, 46 years old, the last education in junior high school who works as a hamlet priest. Informants who are considered to know and understand assunna' culture and understand the method of implementing assunna' culture are actors who carry out assunna culture.

Based on the characteristics of the informants explained that the informants obtained in the study using in-depth interview techniques (In-depth Interview) obtained informants provide information disclosed by the informants. The discussion covered the risk of infection, disease prevention, and the concept of health and illness. The discussion is about the health implications of assunna' cultural anthropological studies of health in the Bontoramba community, Jeneponto Regency. During the in-depth interview, the researchers explained the purpose of this study so that the informants had the same perception as the researcher, the researcher asked if they were willing to be met or contacted again for an interview to complete the data needed if necessary. All informants expressed their agreement.

\subsection{RISK OF INFECTION}

The risk of infection is the risk of the occurrence of several diseases due to the actions or actions of as Sunna' culture that can be observed or even learned. The risk of infection referred to here is the tools and materials as well as the techniques or methods used during the implementation of the as Sunna culture. This can be seen from the informants' answers as follows: Informants' answers on the FGD implementation who said:

"The tool used for cutting is a razor blade then the chicken's blood is taken and applied, and firewood ashes are also given" (FGD I, Thursday 18 October 2020 at 17:06 WITA).

The tool used to cut the covering skin in the implementation of as Sunna culture is a new razor blade. The new razors that are used cannot be guaranteed to be safe or clean from germs, bacteria, and viruses. After the cut skin bleeds, the chicken blood is taken and smeared on the bleeding skin. Chicken blood can be a transmission of chicken disease viruses to children. Firewood ashes are given after being smeared with chicken blood. Firewood ash taken directly from the former cooking area can be a place for bacteria and germs or worms to gather because the cooking area is attached to the soil. Likewise, the usual informants gave different answers saying that:

"We were asked to sit on a banana stem and then told to say two sentences of the creed and then cut it, the razor was used to cut, the part that had been cut was sprinkled directly with ashes, the wood ashes were burned. This ash was previously stored in banana leaves. Don't wash your hands, don't wear gloves. The part of the 
banana stem used is the middle part of the banana stem that is cut" (NFT Interview, Monday 22 October 2020 at 11:11 WITA).

The informant saw that before the circumcision process began, the circumcision officer did not wash his hands or wear personal protective equipment such as gloves. Tools and materials used by circumcision officers can be contaminated with germs, bacteria, and viruses because circumcision officers do not wash their hands and wear medical gloves (hand Schoon) before starting the circumcision process. Circumcision officers direct contact with the blood of a circumcised child can be a way of transmitting disease from a child to a circumcision officer. A different answer from a regular EKT informant who said that:

"After I was asked for the creed, my genitals were immediately grabbed and then clamped with bamboo clips and then cut with a razor blade. The prepared ash is stored in the coconut shell, but I don't remember well whether the ash was put on the cut or not because I didn't see it because my face was covered with a sheath. I didn't see him washing his hands. Likewise, no gloves were used, yes, by not using anything, he just held his hand. Bamboo has properties that are flexible but hard, bamboo is flexible, but we can build houses from bamboo which means that bamboo is strong, so we are expected to have the nature of bamboo, the flexibility of bamboo is interpreted to be open to everyone and the hardness of bamboo means that we can't give up quickly. get good results from the effort. People say coconut can grow anywhere, so it is made a condition so that children who are circumcised can find life anywhere, live a good life and become honest people" (EKT Interview, Sunday, October 21, 2020, at 09:07 WITA).

Two sentences of the creed are said by the child before the circumcision process is carried out. There are also circumcision officers who use bamboo as a substitute for tweezers to clamp the genital skin to be circumcised. The skin that is clamped using bamboo is cut using a razor. Wood ash was provided using coconut shells, but the informant did not remember whether the wood ash was given to the cut wound or not because the informant covered his face using the sarong he was wearing. The face of a child who is circumcised is covered with a sarong so that the child's fear is reduced when the skin is about to be cut. The bamboo used by circumcision officers can be a gathering place for bacteria and germs so that they are prone to infection with bacteria and germs that cause disease. The bamboo is used for clamping and the coconut shell is used as a storage container for ash, which is expected by children to follow the good qualities of bamboo and coconut. The same answer was obtained from the key informant HL who said that:

"He was asked to sit on his seat, namely a banana stem, then he was told to cover his face using a sarong that was worn and then asked to open both thighs. After being examined, sprinkled water three times and circumcised using a razor blade. The way I keep my nails under the skin and then cut. If the blood is out, then the chicken blood is taken together with the genital blood. The chicken's comb is cut, and the blood is taken, after being given chicken blood, it is smeared with ashes and then sprinkled with water three times. Banana stems are cold so they can make blood clot quickly, banana stems are easy to find, and are a requirement for children to be useful for everyone because all parts of a banana can be useful both from the roots to the leaves, the fruit does not need to be questioned anymore. Chicken blood taken from the combs of the cut chicken is then smeared on the bleeding part as a form of unifying the nature of the chicken with the circumcised child, where the child has reached puberty and is expected to follow the nature of the chicken that wakes up quickly at dawn and the independent nature of the chicken. The cock's comb shows masculinity" (HL interview on Tuesday, October 23, 2020, at 17:01 WITA).

The key informant's statement was the same as the previous informant's statement, only the key informant added to water by sprinkling it on the genitals and surroundings before and after the circumcision. The water that is sprinkled first 
is read a prayer and blown into the water. Water that is blown by prayer can be a means of transmitting a disease in which bacteria, germs and viruses are transferred from the circumcision officer to the circumcised child. The seat used is a banana stem because it is cold so it is considered capable of making blood clot quickly and becomes a hope for the community so that the life of a circumcised child can be useful for all people.

From some of the informants' answers above regarding the risk of infection with as Sunna' culture, it shows that after being seated on a banana stem, the village circumcision officer immediately holds the child's genitals without washing their hands first, not disinfecting them and not wearing gloves (hand Schoon). The process of circumcision begins with water splashing three times and after the process is complete, it is sprinkled again three times, where the water that is splashed is first read a prayer and blown into the water. After the tip of the genital skin is cut or discarded, the cut and bleeding skin are smeared with chicken blood, the chicken blood is taken from the razor's comb, after that it is given firewood ashes. One of the informants said that the genital skin was clamped using bamboo and then cut with a razor blade.

\subsection{DISEASE PREVENTION}

Disease prevention is an informant's action that is carried out before the occurrence of a disease regarding the health implications of assume' culture in the Bontoramba community. In this study, disease prevention is meant by messages and a series of actions given related to the as Sunna culture. This can be seen from the answers of the informants who have been obtained during the FGD implementation who say that:

"These ashes are smeared on the part that has been cut as a medicine so that the bleeding can stop. I use firewood ash because it freezes easily when exposed to water which can freeze blood, so the bleeding stops quickly" (HL FGD, Thursday 18 October 2020 at 17:06 WITA).

The firewood ash is believed by the community to be used as medicine to stop the blood from cut wounds. Wood ash is applied by rubbing it with your fingers directly on the skin that has been cut and bleeding. People still believe in traditional medicine that has been taught and practised by previous people until it becomes a hereditary habit now. While the answers of key informants during in-depth interviews:

"So, every time I get circumcised, I check the genitals first to see if it can be circumcised in the village, even though there is no need for a doctor's circumcision or a village circumcision, then proceed with a doctor's circumcision. If it has been checked, then sprinkle water three times as a cleanser and it heals quickly, then cut it with a razor blade and smeared with chicken blood, then I spread ashes so that the blood dries quickly or the blood freezes, so it heals quickly. his blood. Yes, there is a prayer, that water is made because in the name of Allah Subhanahu Wa Taala throws away these bad qualities, this child is in the name of... His son ...., so we did leave a message for that water" (HL interview on Tuesday, October 23, 2020, at 17:01).

Every time the village priest is going to do circumcision, he checks the child's sex first. According to the hamlet priest, the skin that covers the head of the penis is divided into two, namely, there is genital skin that covers the entire head of the penis and there is genital skin that is open and does not cover the entire head of the penis or where urine discharge is not covered by genital skin. If the genital skin does not cover the entire head of the penis, it is enough to circumcise the village, but if the genital skin covers the entire head of the penis, then the village circumcision is still 
carried out and then conveyed to the parents so that the doctor remains circumcised because it is considered unclean. Water is sprinkled three times on the genitals and surroundings because water is believed to cleanse the child of bad traits and can remove uncleanness. Water is also believed to make wound healing heal quickly. The water that is sprinkled is read a prayer first, then blows and a message is deposited into the water in the name of Allah can remove bad and unclean traits and can heal. Genital skin that does not cover the entire head of the penis can still store dirt on the inside of the skin which can cause disease, so medical circumcision is necessary. People still have a high belief in the power of prayer like water that is blown first with prayer. The answers to different NFT informants are by giving messages as stated:

"That part that is cut is given ashes, by sprinkling it. At that time, after the circumcision was performed, the parents said like this, don't step down from the top of the house like horse dung, chicken dung can't be done first, then do it too, if we go down the house we have to wear sandals, the parents say if we step on dirt, one of them was horse droppings, chicken droppings, he said it would be painful he said it would sting, not only did he say it would hurt, he didn't say infection but he said it hurt (NFT interview on Monday, October 22, 2020, at 11:11 WITA).

NFT informants consider the ashes to be a medicine so that bleeding wounds heal quickly. The informants also believed in the myth in the form of taboos from parents who said that after being circumcised and the wound has not healed, it is not permissible to come down from above the house and cannot step on chicken manure and horse manure. If the taboo is violated it will feel pain in the former cut. Parents don't say the infection will just be painful. The taboo that the informant believes is a message so that the child's wounds heal quickly; children are not allowed to come down from the house so they don't go out to play with their friends, who fear that the circumcision wound can bleed again because it is touched with pants while running. While different answers were obtained from informants supporting HR who said that:

"The medicine that was given after the first circumcision was amoxicillin as medicine for speedy healing, mefenamic acid as an anti-pain medication, given according to his age, that's all, continue with TT injections or tetanus shots, either on the spot or at the community health centre, or the community health centre. add dexamethasone for the swelling (HR Interview Monday, October 25, 2020, at 16:03 WITA).

HR informant as a nurse who used to perform medical circumcision, after doing circumcision, antibiotics were given so that the healing was fast, anti-pain, namely mefenamic acid as a pain medication after circumcision disappeared or decreased, which was given according to age. Circumcised children are also given a tetanus shot which can be given on-site or at a community health centre. Dexamethasone is also commonly given as an anti-swelling. Healing a wound can be given drugs so that the wound can heal quickly.

Some of the informants' answers have shown that the prevention of as Sunna' cultural disease is by sprinkling water three times which is first given prayer as a cleanser of bad and unclean qualities and can make wounds heal quickly, then using wood ash so that the blood dries quickly and the wound healed quickly. As for informants who believe in myths from parents, they are not allowed to leave the house, cannot step on horse manure and chicken manure so that the circumcised part does not feel sore and sore. Meanwhile, according to supporting informants, antibiotics, anti-pain, TT injections, and anti-inflammatory are usually given. 


\subsection{SICK HEALTHY CONCEPT}

The concept of Healthy Sick is the impact that is caused by both healthy and sick experienced and what is meant by the concept of healthy and sick in this study is the concept of healthy and sick that is felt by ordinary informants about the health implications of as Sunna' culture in the Bontoramba community. This can be seen from the answers of the informants obtained during the FGD who said that:

"E so far, because I have carried out circumcision for more than 20 years, E there has never been a report or information from his parents that he was sick because of circumcision, except when the bird was cut a lot of people cried, if the village circumcision was the key is simply to release the obligation and the Messenger of Allah did not stipulate or not determine whether village circumcision or doctor circumcision has just been released from the obligation, so take it easy" (HL FGD, Thursday 18 October 2020 at 17:06 WITA).

The key informant has been carrying out his profession as a circumcision officer for 20 years, but no parent has ever reported to him or complained that a child who was circumcised was sick because he had been circumcised in the village. The informant added that except when the genitals were cut, many children cried in pain. The pain that is felt may be due to fear, some even make excuses such as stomach pain and the like, some children run because they don't want to be circumcised but the child is still being chased until it is obtained, and the circumcision is still carried out. People choose the assunna culture because it is an easy thing, where the pain experienced by the child is only minimal and the healing is fast because the skin is cut a little. As for the answers of ordinary informants who are different, the informants say that:

"It hurt when I was circumcised, for two days I was in pain, on the day I was circumcised and the next day, after that I didn't feel it anymore" (Interview I, Saturday, October 20, 2020, at 17:01 WITA).

The informant felt pain when the circumcision was performed. The pain felt by the child who was circumcised was experienced for up to two days, namely on the day of the circumcision until the next day. After that, the informant returned to play with his friends. Meanwhile, the answers obtained from regular NFT informants said that:

"I don't feel pain, when I cut it, I feel the ant bites me, no more pain, never hurts until it heals, never hurts again, never hurts, never hurts, doesn't hurt anymore. (NFT interview on Monday, October 22, 2020, at 11:11 WITA).

The informant only felt pain when the genital skin was cut where the pain was described as being bitten by an ant, after the circumcision process was completed, the informant never felt pain again until the wound healed. The pain experienced by the informants was only minimal because only a few skins were cut. The circumcision technique used in assume' culture was obtained from key informants, namely:

"I put my middle finger on top of the genitals, I put my middle finger under her genitals, my index finger, I pushed it out so that the top skin of the genitals was pointing out, my middle finger, I pushed it in so that the bottom skin was inward then the mother's fingernail. I keep my finger under the top skin as a filler then cut a little of the skin (HL interview on Tuesday, October 23, 2020, at 17:01).

The technique used by key informants is a way to make it easier to cut the genital skin, using this technique is believed to also reduce the risk of scratches on circumcision officers because they use sharp objects, namely razors. 
Some of the informants above show that the concept of healthy and sick has health implications for the as Sunna culture, namely pain that is felt when circumcised, the pain is felt for up to two days at most, there is no swelling. After the circumcision, the circumcised child returns to his usual activities or returns to playing with his friends. Pain for children is considered part of the sacred ritual. The community considers doing as Sunna 'culture only to escape from the obligation, namely, the Prophet did not determine whether to have village circumcision or doctor circumcision so that it was light. The technique used by circumcision officers is believed to reduce the risk of injury from sharp objects to cutting genital skin.

\section{DISCUSSIONS}

\subsection{RISK OF INFECTION}

The risk of infection referred to in the study is the risk of the occurrence of several diseases due to actions or actions when carrying out the as Sunna culture. The risk of infection can be seen from the techniques and tools and materials used in carrying out the as Sunna culture. Based on the results of the FGD (Focus Group Discussion) it was found that after the skin was cut off the ends were given chicken blood and followed by rubbing wood ash on the bleeding part.

Based on the results of in-depth interviews, information was obtained that during the implementation of the assume culture the hamlet priest did not use gloves (Hand Schoon) by circumcising, namely the index finger was placed on the upper skin of the penis and the middle finger was placed on the lower skin of the penis and then the index finger. pushed out and the middle finger was pushed in, while the thumb was placed under the top skin of the penis to be cut, the skin was cut only a little, the important thing was to bleed and give chicken blood, firewood ash was given so that the wound was cut the blood stops quickly or the blood clots quickly and the healing is fast.

Based on the results of research by researchers in the field about the risk of infection, the health implications of assunna' culture in the Bontoramba community, it was found that the village priest did circumcision without using gloves (Hand schoon), the method of circumcision was that the index finger was placed on the upper skin of the penis and the middle finger was placed on the skin. the bottom of the penis then the index finger is pushed out and the middle finger is pushed in, while the thumb is placed on the underside of the upper skin of the penis to be cut, then cut using a razor blade, the cut part is smeared with chicken blood, chicken blood is taken from the comb cut then followed by giving firewood ash which was previously placed on top of a banana leaf, firewood ashes taken from the rest of the fire were to cook rice or cook horse meat.

The implementation of the assunna culture does not apply hand washing before carrying out circumcision practices and does not use personal protective equipment such as hand schools which can pose a risk of infection as stated by Garner and Farvero (1986) in Tietjen et al. (2004) which states that washing hands and the use of hand scoops can prevent disease transmission so that patient and staff safety is maintained.

\subsection{DISEASE PREVENTION}

Disease prevention in this study is a series of actions and messages given during the implementation of the assunna culture. Based on the results of the FGD (Focus Group Discussion) it was found that firewood ash was given to the cut part as a medicine so that the blood stopped quickly. 
While the results of in-depth interviews with the hamlet priest obtained information that disease prevention was carried out by sprinkling water that had been blown with a prayer "Ku parekko saba'ri karaeng Allah ta'ala untuk angpelaki kasipallina iyanu anakna iyanu". Furthermore, the hamlet priest examines the genital skin of the circumcised child, according to hamlet priest, the skin covering the head of the penis is divided into two, namely, there is genital skin that covers the entire head of the penis and there is genital skin that is open and does not cover the entire head of the penis or the urinal discharge is not covered. genital skin. If the genital skin does not cover the entire head of the penis, it is enough to circumcise the village, but if the genital skin covers the entire head of the penis, then the village circumcision is still carried out and then conveyed to the parents so that the doctor remains circumcised because it is considered unclean.

After the skin is cut and bleeding, firewood ashes are then placed on top of the banana leaf by sprinkling or smearing it directly. Firewood ash is taken from the rest of the fire where rice is cooked, or horse meat is cooked. Wood ash is believed to make the bleeding stop quickly or to make the blood clot quickly and the wound dries quickly. People still believe in the myth that after being circumcised, you should not step on chicken manure and horse manure, until the wound is healed. If the taboo is violated, it will feel pain or pain in the circumcised part. It has become a culture that has been passed down from generation to generation.

The foreskin is a tissue that is vulnerable to HIV transmission. The increased risk of HIV transmission among men with the greatest foreskin surface area may be due to the presence of large numbers of HIV target cells in the inner preputial mucosa exposed to infected vaginal fluids during sexual intercourse. It is also possible that men with a larger foreskin surface area may be more susceptible to trauma to the foreskin mucosa during sexual intercourse, increasing the risk of HIV transmission Kigozi et al. (2009).

Based on research in the field on disease prevention on the health implications of assunna' culture in the Bontoramba community, it was found that firewood ashes were placed on top of banana shoots, the circumcision process was started by sprinkling water three times. Then the genital skin was cut. After bleeding, it was given. Chicken blood on the wound is then followed by giving ashes by smearing it directly and closing it with water sprinkled three times. People have still believed in traditional medicine such as firewood ashes since ancient times.

\subsection{SICK HEALTHY CONCEPT}

The concept of health and illness referred to in this study is the subjective feeling of pain felt by children when circumcised and the meaning understood by parents and village circumcision officers about the health implications of as Sunna' culture in the Bontoramba community. Based on the information obtained from the FGD (Focus Group Discussion) it is known that children who are circumcised feel sick when doing the cutting process and their parents have more dominant cultural beliefs than health.

Based on the results of interviews with circumcised children, information was obtained that pain was felt when the skin was cut. The pain felt differently, some felt like they were just bitten by ants, and some were so sick that they cried. The pain felt on the day of the circumcision, and some felt it until the next day. The community considers village circumcision to be carried out only to release obligations as Muslims. According to the community, the Messenger of Allah did not stipulate that village circumcision or medical circumcision should be performed, so it is enough to keep it simple. It is said to be simple because the process is easy, and the pain felt by the child is minimal because only a small part of the skin is taken. 
As for the implementation of assuna' culture carried out in the Bontoramba community, namely: 1) Water is sprinkled three times on the genitals; 2) The middle finger is placed on the bottom of the pubic; 3) The index finger on the top of the pubic; 4) The thumb is placed under the genital skin on the upper genital skin; 5) The middle finger pushes the skin in; 6) The index finger pushes out the skin until the upper genital skin is on the top of the thumbnail; 7) Children are asked to say two sentences of creed; 8) The upper skin is cut slightly using a razor blade; 9) The chicken's comb is cut using a razor blade, the chicken's blood is taken from the chicken's comb using the index finger then the chicken blood is applied to the cut and bleeding skin; 10) Next, sprinkle firewood ashes on the cut genitals; 11) Water is sprinkled again three times; 12) Done.

This is different from the medical implementation of circumcision or circumcision, which already have fixed procedures and are equipped with medical materials and equipment that meet health requirements. Based on the process of implementing the as Sunna culture and medical circumcision procedures, it can be seen that they are much different, starting from the preparation, tools and materials used and the cutting procedures carried out. The procedure for medical circumcision is carried out starting with washing hands while the implementation of the as Sunna culture is not, this is done as a form of preventing the risk of infection for both the circumcision operator and the patient. Next, use gloves (hand shoons) which are personal protective equipment when taking action. One of the important parts in the implementation of medical circumcision is controlling bleeding during the circumcision process to avoid post-circumcision bleeding and the medical circumcision process ends by washing hands again so that the hands are clean of liquid or blood if any sticks to the hands to avoid the risk of infection.

\section{CONCLUSIONS AND RECOMMENDATIONS}

The conclusions of this study are 1) The risk of infection in the as Sunna culture in the Bontoramba community, namely not applying handwashing with soap, not wearing gloves (hand schoon), not carrying out disinfection, and the use of firewood ash can trigger swelling of cut wounds; 2) Prevention of infection in the as Sunna culture in the Bontoramba community, namely by sprinkling water three times as a cleanser from the bad qualities of the child and faster healing of cut wounds, where the water is first to read a prayer and then blown into the water. Giving firewood ashes as a medicine that has been believed for a long time can make a bleeding stop or blood clot quickly and heal quickly; 3 ) The concept of healthy and sick in the as Sunna culture in the Bontoramba community, namely the pain felt by the child is a sacred part of the circumcision procession because circumcision for the community is integral to the prevailing customs.

It is recommendefd that health workers provide counseling or socialization to the community about the importance of medical circumcision, establish relationships with traditional and religious stakeholders, and formulate procedures for integrating traditional medicine into modern medicine.

\section{ACKNOWLEDGEMENTS}

The authors would like to thank the Dean of the Faculty of Public Health, the Universitas Pejuang Republic of Indonesia who has given space to the author in completing this research. Thanks, are also conveyed to the informants who have taken the time to provide information to researchers, as well as to the Central Statistics Agency, Jeneponto District Government, Jene Ponto District Health Office and Bontoramba Health Center who have been willing to provide additional information related to this research. 


\section{REFERENCES}

Drain, P. K., Halperin, D. T., Hughes, J. P., Klausner, J. D., \& Bailey, R. C. (2006). Male Circumcision, Religion, and Infectious Diseases : An Ecologic Analysis of 118 Developing Countries. BMC Infectious Diseases, 6(1), 1-10. Retrieved from https://doi.org/10.1186/1471-2334-6-172

Erviana, E. (2014). Sunat, Menekan Risiko HIV sampai Kanker. Retrieved February 5, 2018, from KOMPAS.com website : Retrieved from https://www.kaskus.co.id/thread/5486306c148b466e118b456a/yangbelum-sunat-masuk-sunat-menekan-risiko-hiv-sampai-kanker /

Fatmawati, P. (2015). Nilai-Nilai Dalam Upacara Assunna Pada Masyarakat Jeneponto Provinsi Sulawesi Selatan. Jurnal Walasuji, 6(1).

Hartoyo, E. P. (2015). Hubungan antara Karakteristik Demografi dengan Pengetahuan Mobilisasi Dini pada Pasien Post Operasi Laparatomi di RS PKU Muhammadiyah Bantul. Universitas Muhamadiyah Yogyakarta.

Kigozi, G., Wawer, M., Ssettuba, A., Kagaayi, J., Nalugoda, F., Watya, S., ... Lutalo, T. (2009). Foreskin Surface Area and HIV Acquisition in Rakai, Uganda (Size Matters). In AIDS (London, England) (Vol. 23). NIH Public Access. Retrieved from https://doi.org/10.1097/QAD.0b013e328330eda8

LeMone, P., Burke, K. M., \& Bauldaff, G. (2015). Buku Ajar Keperawatan Medikal Bedah. Jakarta : EGC.

Maksum, A. (2015). Politik Identitas Masyarakat Tengger dalam Mempertahankan Sistem Kebudayaan dari Hegemoni Islam dan Kekuasaan. El-HARAKAH (TERAKREDITASI), 17(1), 18-35. Retrieved from https://doi.org/10.18860/el.v17i1.3083

Ramli, A. (2015). Ritual Keagamaan Masyarakat Alifuru Desa Leku Kecamatan Namrole Kabupaten Buru Selatan. Biosel: Biology Science and Education, 4(2), 69-84. Retrieved from https://doi.org/10.33477/bs.v4i2.540

Tietjen, L., Bossemeyer, D., \& McIntosh, N. (2004). Panduan Pencegahan Infeksi untuk Fasilitas Pelayanan Kesehatan dengan Sumber Daya Terbatas. Jakarta : Yayasan Bina Pustaka Sarwono Prawirohardjo 